\title{
Delimitation and coherence of functional and administrative regions
}

Citation for published version (APA):

Cörvers, F., Hensen, M. M., \& Bongaerts, D. (2009). Delimitation and coherence of functional and administrative regions. Regional Studies, 43(1), 19-31. https://doi.org/10.1080/00343400701654103

Document status and date:

Published: 01/01/2009

DOI:

10.1080/00343400701654103

Document Version:

Publisher's PDF, also known as Version of record

\section{Please check the document version of this publication:}

- A submitted manuscript is the version of the article upon submission and before peer-review. There can be important differences between the submitted version and the official published version of record.

People interested in the research are advised to contact the author for the final version of the publication, or visit the DOI to the publisher's website.

- The final author version and the galley proof are versions of the publication after peer review.

- The final published version features the final layout of the paper including the volume, issue and page numbers.

Link to publication

\footnotetext{
General rights rights.

- You may freely distribute the URL identifying the publication in the public portal. please follow below link for the End User Agreement:

www.umlib.nl/taverne-license

Take down policy

If you believe that this document breaches copyright please contact us at:

repository@maastrichtuniversity.nl

providing details and we will investigate your claim.
}

Copyright and moral rights for the publications made accessible in the public portal are retained by the authors and/or other copyright owners and it is a condition of accessing publications that users recognise and abide by the legal requirements associated with these

- Users may download and print one copy of any publication from the public portal for the purpose of private study or research.

- You may not further distribute the material or use it for any profit-making activity or commercial gain

If the publication is distributed under the terms of Article $25 \mathrm{fa}$ of the Dutch Copyright Act, indicated by the "Taverne" license above, 
This article was downloaded by: [University of Maastricht]

On: 24 July 2009

Access details: Access Details: [subscription number 786928495]

Publisher Routledge

Informa Ltd Registered in England and Wales Registered Number: 1072954 Registered office: Mortimer House, 37-41 Mortimer Street, London W1T 3JH, UK

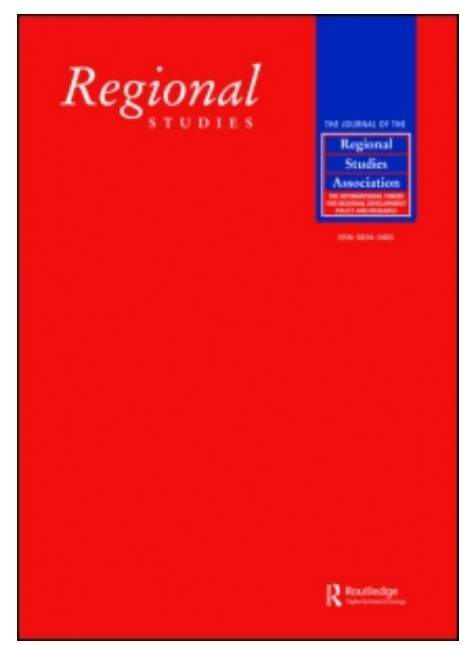

\section{Regional Studies}

Publication details, including instructions for authors and subscription information: http://www.informaworld.com/smpp/title content=t713393953

\section{Delimitation and Coherence of Functional and Administrative Regions}

Frank Cörvers a; Maud Hensen ${ }^{\text {b}}$; Dion Bongaerts ${ }^{c}$

a Research Centre for Education and the Labour Market (ROA), Maastricht University, Maastricht, the Netherlands ${ }^{\mathrm{b}}$ Hogeschool Zuyd, Heerlen, the Netherlands ${ }^{\mathrm{C}}$ Universiteit van Amsterdam, Amsterdam, the Netherlands

First Published:February2009

To cite this Article Cörvers, Frank, Hensen, Maud and Bongaerts, Dion(2009)'Delimitation and Coherence of Functional and Administrative Regions', Regional Studies,43:1,19 - 31

To link to this Article: DOI: $10.1080 / 00343400701654103$

URL: http://dx.doi.org/10.1080/00343400701654103

\section{PLEASE SCROLL DOWN FOR ARTICLE}

Full terms and conditions of use: http://www.informaworld.com/terms-and-conditions-of-access.pdf

This article may be used for research, teaching and private study purposes. Any substantial or systematic reproduction, re-distribution, re-selling, loan or sub-licensing, systematic supply or distribution in any form to anyone is expressly forbidden.

The publisher does not give any warranty express or implied or make any representation that the contents will be complete or accurate or up to date. The accuracy of any instructions, formulae and drug doses should be independently verified with primary sources. The publisher shall not be liable for any loss, actions, claims, proceedings, demand or costs or damages whatsoever or howsoever caused arising directly or indirectly in connection with or arising out of the use of this material. 


\title{
Delimitation and Coherence of Functional and Administrative Regions
}

\author{
FRANK CÖRVERS*, MAUD HENSEN† and DION BONGAERTS $\ddagger$ \\ * Research Centre for Education and the Labour Market (ROA), Maastricht University, PO Box 616, NL-6200 MD Maastricht, \\ the Netherlands. Email: f.coervers@roa.unimaas.nl \\ †Hogeschool Zuyd, PO Box 550, NL-6400AN Heerlen, the Netherlands.Email: m.hensen@hszuyd.nl \\ ‡Universiteit van Amsterdam, Roeterstraat 11, NL-1018 WB Amsterdam, the Netherlands. Email: d.g.j.bongaerts@uva.nl
}

(Received January 2006: in revised form April 2007)

Cörvers F., Hensen M. and Bongaerts D. Delimitation and coherence of functional and administrative regions, Regional Studies. The paper tests whether functional regions in the Netherlands show more labour market coherence between the municipalities included in them than the Dutch administrative regions. It turns out that regional disparities are not significantly smaller within functional than within administrative regions with respect to income level, housing prices, employment rate, and unemployment rate. It is argued that the numerous functional delimitations of the labour market that have been made for many countries in other studies are only useful for policy-making if they clearly outperform the administrative delimitations with respect to some relevant indicators of labour market coherence or regional disparities.

Functional regions Commuting Travel-to-work areas (TTWA) Regional disparities

CÖRvers F., Hensen M. and BONGAERTS D. 功能行政区的定界与连续性, 区域研究。本文试图考察, 荷兰的功能区中各 自治区间是否存在比丹麦的行政区更明显的劳动力市场连续性。研究结果表明,就收入水平、房产价格、就业率以 及失业率而言, 功能区域内的地区性差异相对于行政区而言并未显著减小。研究认为, 即便功能性定界显著地优 于根据劳动力市场连续性相关指标或者地区性差异而进行的行政定界，这种在其他相关研究中提及到的、业已在 很多国家实施的劳动力市场功能定界，也仅对政策制定有用。

\section{功能区＼cjkstart通勤交通(TTWA) 地区性差异}

Cörvers F., Hensen M. et Bongaerts D. Délimitation et cohérence des régions fonctionnelles et administratives, Regional Studies. Nous vérifions si les régions fonctionnelles des Pays-Bas présentent davantage de cohérence dans le marché du travail entre les municipalités englobées dans celles-ci que les régions administratives néerlandaises. Il s'avère que les disparités régionales ne sont pas vraiment moindres dans les régions fonctionnelles que dans les régions administratives du point de vue du niveau de revenus, du prix des logements, du taux d'emploi et du taux de chômage. Nous soutenons que les nombreuses délimitations fonctionnelles du marché du travail qui ont été établies pour de nombreux pays dans d'autres études ne sont utiles pour la prise des décisions politiques que si elles se montrent nettement plus performantes que les délimitations administratives par rapport à certains indicateurs pertinents de la cohérence du marché du travail ou des disparités régionales.

Régions fonctionnelles Migrations quotidiennes Travel-to-work areas (TTWA - aires fonctionnelles urbaines) Disparités régionales

Cörvers F., Hensen M. und Bongaerts D. Abgrenzungen und Kohärenz von funktionalen und Verwaltungsregionen, Regional Studies. Wir überprüfen, ob die funktionalen Regionen der Niederlande hinsichtlich des Arbeitsmarkts mehr Kohärenz zwischen den Gemeinden der einzelnen Regionen aufweisen als zwischen den holländischen Verwaltungsregionen. Wie sich herausstellt, fallen die regionalen Disparitäten innerhalb der funktionalen Regionen nicht signifikant kleiner aus als innerhalb der Verwaltungsregionen, was das Einkommensniveau, die Hauspreise, das Beschäftigungsniveau und die Arbeitslosenzahlen angeht. Wir argumentieren, dass die zahlreichen funktionalen Abgrenzungen des Arbeitsmarkts, die in anderen Studien für viele Länder geschaffen wurden, zur politischen Gestaltung nur nützlich sind, wenn sie den verwaltungstechnischen Abgrenzungen hinsichtlich einiger relevanter Indikatoren für die Arbeitsmarktkohärenz oder die regionalen Disparitäten klar überlegen sind.

Funktionale Regionen Pendlerverkehr Arbeitsmarktregionen Regionale Disparitäten

Cörvers F., Hensen M. y Bongaerts D. La delimitación y coherencia de las regiones funcionales y administrativas, Regional Studies. En este artículo comprobamos si la coherencia del mercado laboral entre las municipalidades de las regiones funcionales de 
los Países Bajos es mayor que la coherencia entre las regiones administrativas holandesas. Observamos que las desigualdades regionales no son significativamente menores en las regiones funcionales que en las regiones administrativas con respecto al nivel de ingresos, los precios de la vivienda y las tasas de empleo y desempleo. Sostenemos que las numerosas delimitaciones funcionales del mercado laboral que se han realizado para muchos países en otros estudios son sólo útiles para la elaboración de políticas si claramente funcionan mejor que las delimitaciones administrativas con respecto a algunos indicadores relevantes de la coherencia del mercado laboral o de las desigualdades regionales.

Regiones funcionales Desplazamientos diarios Cuenca de empleo Desigualdades regionales

JEL classifications: J61, R23

\section{INTRODUCTION}

The definition of a regional labour market is very important in the light of regional labour market policies (BALL, 1980). In particular for research and policymaking purposes, the delimited areas should exhibit functional similarities. The economic diversity within an administratively defined region might be so large that comparison between regions is not justified. The decisions made concerning the planning, distribution, and allocation of resources among the various regions derived are not likely to be the most effective and meaningful relative to the decision that would be made if the underlying regional patterns were known (AMEDO, 1968). For example, areas with high unemployment rates but administratively falling within regions with low average unemployment rates may receive no assistance from the national government or the European Union.

The dominant concept in defining functional regions is that of labour markets, as is illustrated by the substantial literature in this field by, for example, Andersen (2002), Baumann et al. (1996), Coombes et al. (1986), CASAdo-Díaz (2000), Eurostat (1992), Fox and Kumar (1965), Killian and Tolbert (1993), and Newell and Papps (2002). For the delimitation of functional labour market regions commuting flows are used in most Organization for Economic Co-operation and Development (OECD) countries (OECD, 2002). Commuting conditions such as distance, closeness, commuting thresholds, and travel times determine the magnitude of the commuting flows between areas. On the basis of commuting flows, a functional region can then be defined as a region in which a large proportion of the workers both live and work.

However, it might be difficult for local planning authorities to interpret statistical information as well as to set policy goals with regard to a different division of areas than the administrative division (COOMBES and Openshaw, 1982; Green and Coombes, 1985). It might be even more difficult and costly to reorganize local government structure according to a particular functional division of regions. Therefore, a functional regionalization should have clear benefits over the administrative regionalization to make it really valuable for policy-makers. This might be the case if the labour market areas within the functional regions are significantly more coherent than within the administrative regions.

The issue of regionalizing countries into functional regions can be regarded as a modifiable areal unit problem (MAUP; e.g. OPENSHAW, 1984; UNWIN, 1996), which consists of both a scale and an aggregation problem. The scale problem refers to the choice of the appropriate number of regions, whereas the aggregation problem refers to the choice of an appropriate regionalization (BAUMANN et al., 1996). Labour market studies in which data on basic spatial units - in the present paper municipalities - are aggregated by using administratively defined regions do generally not inform about the use of other delineations. Due to the potentially infinite options to aggregate the data, one should be aware of the spatial variation of the data, particularly when using more or less arbitrary and 'modifiable' boundaries between areas.

The aim of this paper is to examine whether the coherence of the functional labour market regions, which are carefully delimited without using arbitrary criteria, is larger than the coherence of the administrative defined labour market regions. The larger the coherence of the areas within the delimited regions, the larger the heterogeneity between the delimited regions is expected to be for particular measures related to the economy and the labour market. The comparison of different regionalizations using economic indicators has hardly been examined in the field of labour economics. The present authors will attempt to make a contribution in this field by testing for the labour market coherence of different functional and administrative regionalizations for the case of the Netherlands.

Labour market coherence will be measured by four economic indicators that are commonly used in studies on regional disparities (e.g. OECD, 2005, ch. 2): income level, housing prices, employment rate, and unemployment rate. Moreover, the use of these indicators will be justified in a commuting model of the labour market. For these indicators it will be tested whether functionally defined regions show more coherence between the municipalities included in it than the administratively defined regions. According to the commuting model presented in this paper, low commuting flows between functional regions 
should go hand in hand with large interregional differences in wages, housing prices, employment, and unemployment rates. The new approach in the paper is that the administrative and functional regions are linked to these measures of regional economic performance to obtain an idea of which of the regionalizations should be preferred.

The paper falls into two parts. The second section refers to the first part and discusses the relevant literature on delimitation studies. Furthermore, it explains the delimitation method used and shows the results of applying this method on the commuting data of the Netherlands at four different scale levels. The third section refers to the second part and starts with a commuting model of the labour market. The model underpins the use of the four economic indicators mentioned above for the empirical testing on labour market coherence. Next, the third section discusses the results of this testing. The fourth section concludes.

\section{REGIONALIZATION BASED ON TRAVEL-TO-WORK FLOWS}

Previous studies

The use of delimitations of functionally defined regions varies between countries (OECD, 2002). In Great Britain, labour market areas have been defined to analyse labour market phenomena, calculate unemployment rates, identify assisted areas for industrial policies, and reorganize local government. These labour market areas are known as travel-to-work areas (TTWA; Coombes et al., 1986; Office for National StatISTICS (ONS) and COOMBes, 1998; CoOmBes, 2005). They are the result of a delimitation procedure using the direct and indirect relationships between municipalities by analysing the behaviour of individual commuters. In addition, for a number of other European countries the same regionalization algorithm has been undertaken (Eurostat, 1992). For some countries the results of more or less the same regionalization algorithm have been published in separate studies. These countries include Denmark (ANDERSEN, 2002), the region of Valencia in Spain (CASADO-DíAZ, 2000), Italy (SFOrZi et al., 1997), and New Zealand (Newell and PAPps, 2002).

The delimitation procedure of TTWAs was developed to generate the maximum possible number of areas with a self-containment level of at least $75 \%$ (SMART, 1974) and a minimum size of the area of 3500 resident workers. Within the area, at least $75 \%$ of the jobs should be fulfilled by the residents of that area (demand-side self-containment) and at least $75 \%$ of the residents should work in the area (supply-side selfcontainment). In addition, a 70\% threshold was accepted if the size of the area exceeded 20000 residents. The municipalities with the highest self-containment levels are selected as the starting point for the delimitation procedure. However, the determination of the threshold values determines to a great extent the number of local labour market areas defined. ${ }^{1}$ Lower threshold values would yield more local labour market regions, as a result of which the usefulness of the delimitation for policy-making might be reduced. Other absolute threshold values to select employment centres are used, for example by GiUlliano and Small (1991), who defined contiguous employment areas in the Los Angeles region of the USA as areas with at least ten workers per acre or more than 10000 workers. Moreover, VAN DER LAAN and SCHALKE (2001) argued that the use of situation-dependent absolute figures is responsible for different classifications that depend on the country and the period of analysis. To avoid the problems related to the use of absolute figures when defining TTWAs, they used relative instead of absolute criteria to delimit local labour market areas in the Netherlands. Nevertheless, the choice of these relative criteria also seems to be rather arbitrary.

The more or less arbitrary nature of many delimitation procedures is illustrated by the fact that the regionalization algorithm had to be adapted with respect to some thresholds to obtain 'satisfactory' results in the studies that used the algorithm by Coombes (see above). The 'fine-tuning' for each country is considered to be necessary to deal with the wide variety of local labour market areas. However, such fine-tuning can be rather arbitrary since:

the TTWAs form only one of the innumerable possible different aggregations ... to achieve the goal of $75 \%$ selfcontainment. $^{2}$

(CoOmbes and Openshaw, 1982, p. 142)

Therefore, the present authors do not agree with COOMBEs et al. (1986) that this flexible multistage aggregation approach should be preferred above the alternative approach applied by, for example, BROWN and Holmes (1971) and MAsser and Brown (1975). Although the alternative approach has been criticized for being too deterministic and solely based on numerical taxonomy principles and statistical objectives (CoOmbes et al., 1986), the present authors prefer this approach since it does not require the modification of criteria in a rather arbitrary way.

The different methods in the alternative approach are reviewed and tested by, for example, MASSER and Scheurwater (1980), Fischer (1980), and BAUMANN et al. (1996). From these reviews it turns out that there is no clear a priori advantage of one or the other method. The present authors have chosen to delimit regions in the Netherlands by using the Markov analytic functional distance approach, which transforms the interaction matrix of commuting flows between municipalities into an mean first passage time (MFPT) matrix. This method is one of the most widely used regionalization methods in the alternative approach, and is intuitively appealing because the cells 
of the MFPT matrix represent functional distances between municipalities.

This paper is mainly interested in whether the functional division of regions can outperform the administrative division with respect to the four economic indicators mentioned in the Introduction:

The fundamental question of which regionalization should be chosen should be decided on the basis of a set of relevant criteria, such as $R^{2}-, t$-values and a priori signs, etc.

(BAUMANN et al., 1996, p. 380)

By using the economic indicators as the relevant criteria in the analysis, the present paper deals with the aggregation problem. The paper will cope with the scale problem by performing the analysis on the comparison between the functional and the administrative division at different scale levels.

\section{Methods}

Following BROwN and Holmes (1971) and BAUMANN et al. (1996), the present authors first transform the standard interaction matrix of commuting flows between municipalities into a MFPT matrix (see Appendix 1), and then cluster municipalities that have more interaction with each other than with municipalities outside the cluster. This aggregation method aims to maximize within-region commuting flows by merging the two adjacent municipalities (or clusters) with the smallest distances expressed by the MFPT indicators, that is the greatest mutual interaction in commuting flows. Setting the maximum number of clusters preferred, this aggregation method leads to an optimal delimitation of functional regions.

Given the initial distance matrix, the clustering procedure can be started. The paper follows the method proposed by WARD (1963), which has also been used by, for example, MAsSer and Scheurwater (1980) and BAUMANN et al. (1996). Two municipalities/clusters, $i$ and $j$, are only clustered if they are adjacent. The procedure subsequently clusters the two municipalities with the smallest $d$ (functional distance). The new distances from $a$ to all other clusters are calculated by minimizing the variance within clusters. The new distance $d(a, r)$ between a new cluster $a$ consisting of $p$ and $q$ to another region/cluster $r$ is calculated according to the formula:

$$
\begin{aligned}
d(r, a) & =d(r, p \cup q) \\
& =\frac{\left(n_{P}+n_{r}\right) \cdot d(p, r)+\left(n_{q}+n_{r}\right) \cdot d(q, r)-n_{r} \cdot d(p, q)}{n_{P}+n_{q}+n_{r}}
\end{aligned}
$$

where $n_{x}$ is the number of elements in cluster $x$.

\section{Commuting data}

For the delimitation analyses the travel-to-work ${ }^{3}$ data (OVG, 'Onderzoek VerplaatsingsGedrag', for 2001,
1991, and 1992) from Statistics Netherlands, which observed the travelling behaviour of a sample from the Dutch population, have been used. This travelling behaviour can be classified according to the motivation of the mobility decision. Apart from the decision to travel to work, other motives to travel are also observed, such as shopping or sports. To delimit the Netherlands, only the home-to-work journey is used as a motive for the mobility decision.

The number of observations used in the delimitation analysis of 2001 was 39280 . Since the number of observations was substantially lower for 1991, the OVG data for 1992 were also used as if the data sets were from one year. The remainder of the paper will refer to '1991' when the data from 1991/92 are used. The total number of observations for these two years was still only 5875. Given the number of the 484 remaining municipalities, the regionalization of 1991 should be regarded as less reliable than the regionalization of 2001. Due to a lack of data, the five islands in the north ('Waddeneilanden') could not be clustered in the 2001 and 1991 delimitation analyses.

The average travel distance the workers travelled to reach their work location was about $16 \mathrm{~km}$ in 2001 . In 1991, workers travelled on average $13 \mathrm{~km}$. The commuting behaviour of workers has therefore changed over time. Hence, the delimitation of regions might have changed over time.

\section{Results of the delimitations with commuting flows}

The method described above allows one to produce any number of functional regions. The number of functional regions to be generated in the delimitation procedure was set equal to the number of administratively defined regions in the Netherlands in order to compare the coherence of the regions in the administrative and functional divisions (see the next section). The text below will discuss four different administrative divisions of the Netherlands. For reasons of space and readability, only the figures of the four-region administrative and functional divisions of 2001 are shown. In BONGAERTS et al. (2004) the figures for 1991 and for the 12,24 , and 40 divisions of administrative and functional regions can be found.

Eurostat uses the Nomenclature of Territorial Units for Statistics (NUTS) to divide countries into regions. According to NUTS1, the Netherlands is divided into four country parts: north, south, east. and west. Fig. 1 shows this administrative delineation of the Netherlands. Since the Netherlands is divided into four administrative regions in NUTS1, four functional regions were generated in accordance with the delimitation procedure from the preceding section.

Fig. 2 presents the derived delineation for four functional regions in 2001. The functional division into four regions of the Netherlands is evidently different from the administrative four-region division. It appears that 


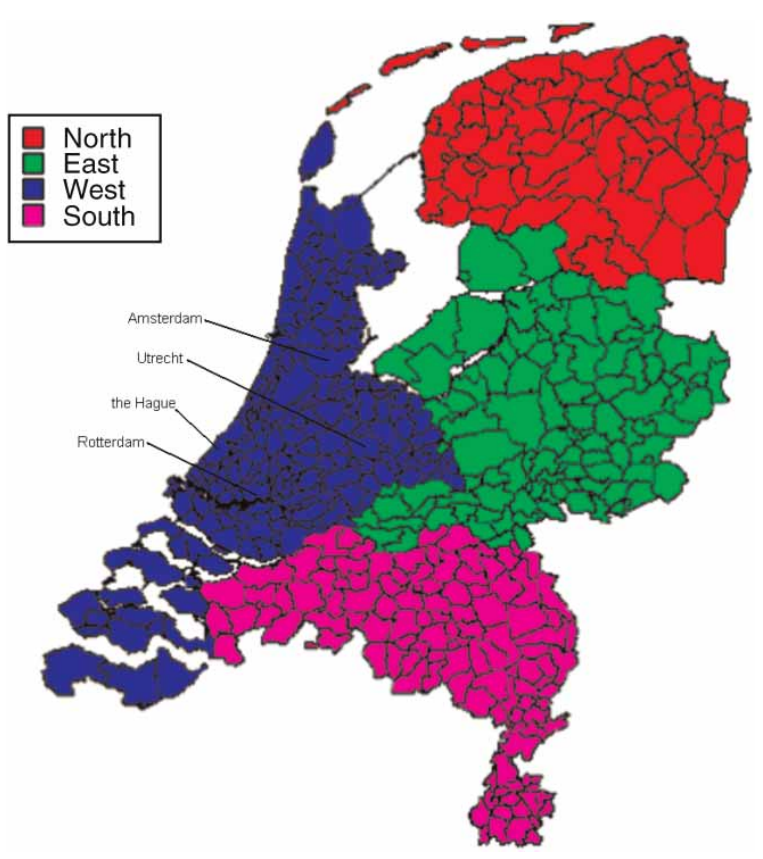

Fig. 1. Four administrative regions (NUTS1) of the Netherlands

the Utrecht region is a separate regional labour market according to the delineation into functional regions. Furthermore, the Zeeuws-Vlaanderen region, consisting of three municipalities, can also be seen as a separate more homogeneous - region. This can be easily explained by the absence of a bridge or tunnel across the Westerschelde estuary to connect Zeeuws-Vlaanderen and Zuid-Beveland. ${ }^{4}$

Moreover, the functional delineation based on commuting flows suggests that the northern part of the

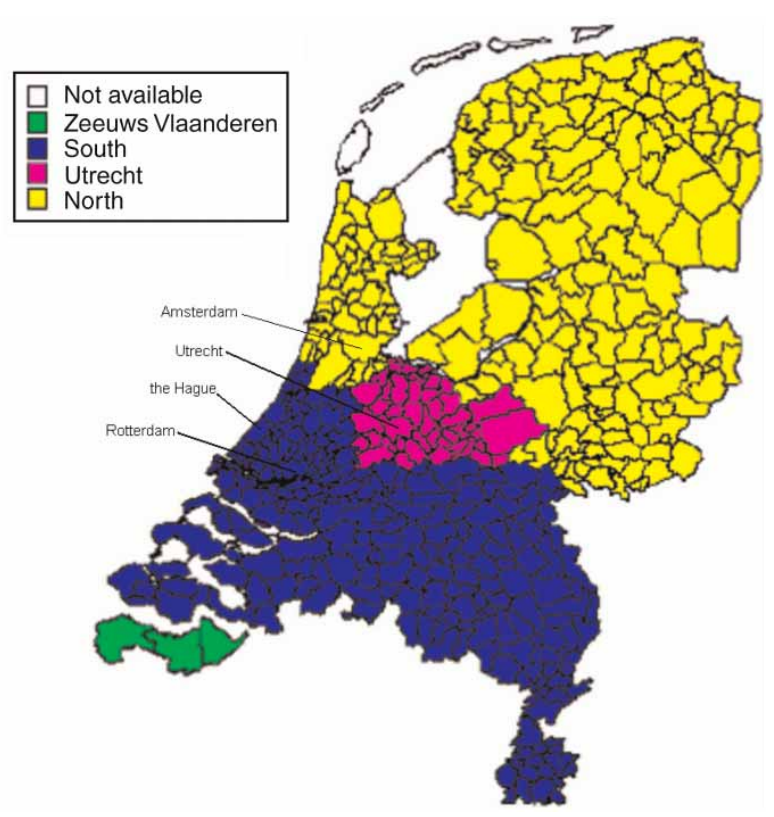

Fig. 2. Four functional regions of the Netherlands, 2001
Netherlands interacts more with the western and the middle part of the country than is suggested by the administrative division. The same is true for the southern part. Apparently, there is more north-south than east-west distinction between regions. This can be partly explained by the River Rhine flowing from east to west into the North Sea. Probably related to the course of the Rhine, the border between the functional regions Utrecht and South is almost the same as in the administrative four-division or the administrative 12-division of provinces (see below). However, in the west the border between the functional regions North and South follows the administrative border between the provinces North Holland and South Holland instead of the Rhine.

The functional division into four regions also illustrates the strong polycentricity of the Randstad Holland region (e.g. Musterd and VAn Zelm, 2001), which consists of the cities of Amsterdam, Utrecht, the Hague, and Rotterdam. In the functional division the latter two cities are part of the south and the cities of Amsterdam and Utrecht are situated in different functional regions, whereas in the administrative division the Randstad cities belong to one region (i.e. west) (Fig. 1). A recent report by the Netherlands Institute for Spatial Research (RitsemA VAN ECK et al., 2006) concludes that the Randstad cannot be regarded as a single cohesive whole, although this holds to a lesser extent for commuting patterns than for business relationships and shopping expeditions between the urban regions.

The regional division of the Netherlands at the NUTS2 level refers to the 12 provinces of the Netherlands, which fall within the boundaries of the NUTS1 regions. These provinces represent the administrative layer in between the national government and the local municipalities. A large share of the regional budgets for policy planning is distributed over the provinces. The division of the Netherlands into 12 functional regions has been compared with the Dutch division in 12 provinces.

Other administrative delimitations that are compared with the functional delimitations include the RBA division of 28 regions and the COROP division of 40 regions (NUTS3). The RBA division refers to a delimitation of labour market areas, formerly used by the national employment agency. The COROP regions were delimited according to the nodal division principle, which means that every region contains a central municipality. Although the COROP regions can be considered more or less as functional regions, an additional requirement for this delimitation was that the COROP regions were situated within the boundaries of the provinces. Both the RBA and the COROP divisions have been widely used in structural analyses of labour markets for analysing territorial disparities, but also by specific administrative bodies to plan their policies. 
In general, the delimitations using 1991 commuting flows lead to more small regions than in 2001. An explanation for this could be the shorter travel distances. In 1991, workers might have been less able - due to a less favourable infrastructure or them not having a car - or less willing to commute to reach their work location than in 2001. If commuting distances further increase during the next decade in the Netherlands, then there will hardly be any small regions that represent more or less closed labour markets.

\section{TESTING FOR THE COHERENCE OF REGIONS}

\section{A commuting model of the labour market}

This subsection will analyse how commuting reduces wage inequality between regions. ${ }^{5}$ It is hypothesized that large commuting flows between regions will reduce interregional wage differences, and interregional differences in housing prices, employment, and unemployment rates. Therefore, regions can be aggregated to one coherent region if the commuting flows between them are large.

The starting point is a classical supply-demand representation of the labour market with $\alpha$ and $\beta$ representing the exogenously given parameters. In this model the labour demand function can be characterized by:

$$
L_{D, t}^{R}=\beta_{1}^{R}-\beta_{2}^{R} * W_{t}^{R}
$$

where $W_{t}^{R}$ is the real average wage earnings per worker; and $R$ denotes regions $A$ and $B$. Furthermore, $t$ refers to the period before and after commuting is allowed, where in period $1(t=1)$ no commuting is allowed and in period $2(t=2)$ it is. The labour supply function can be characterized by:

$$
L_{S, t}^{R}=\alpha_{1}^{R}-\alpha_{2}^{R} * W_{t}^{R}
$$

When regional labour supply and demand in period 1 are equal, the labour market in region $R$ is in equilibrium. That is, $L_{D, 1}^{R}=L_{S, 1}^{R}$. Setting (1) equal to (2) yields the equilibrium wage level for both regions $(A$ and $B)$ in period 1:

$$
W_{1}^{R *}=\frac{\alpha_{1}^{R}-\beta_{1}^{R}}{-\beta_{2}^{R}-\alpha_{2}^{R}}
$$

where $\alpha_{2}^{R}>0$ and $\beta_{2}^{R}>0$ are the wage elasticities of supply and demand, respectively. It follows that for $W_{1}^{R^{*}}$ to be positive, $\alpha_{1}^{R}<\beta_{1}^{R}$.

In period 2, commuting is allowed. Assume that in period $1 W_{1}^{A *}>W_{1}^{B}$. This will stimulate workers to commute from $B$ to $A$. However, workers usually have to make costs to travel or to cross natural or psychological barriers. These costs are related to the so-called commuting conditions mentioned in the first section. Suppose that individuals are confronted with fixed costs $F$ if they commute from region $B$ to region $A$. The equilibrium wage level (if commuting between $A$ and $B$ takes place), becomes:

$$
W_{2}^{A *}=W_{2}^{B *}+F
$$

where $F \geq 0$, and $W_{2}^{A^{*}}<W_{1}^{A^{*}}$ and $W_{2}^{B^{*}}>W_{1}^{B^{*}}$. The higher wage level in region $A$ in period 1 leads to a commuting flow from region $B$ to $A$, which in turn decreases the wage level in region $A$ and increases the wage level in $B$. It can be proved that there will be no commuting if the fixed costs $F$ are too large, i.e. $W_{1}^{A^{*}} \leq$ $W_{1}^{B^{*}}+F$. Thus, commuting between regions $A$ and $\bar{B}$ starts only if $W_{1}^{A^{*}}-W_{1}^{B^{*}}>F$ and stops in period 2 if equation (4) is fulfilled.

The commuting flow $L_{C}^{A}$ from region $B$ to region $A$ is equal to the difference between labour demand and supply in region $A$ (or $B$ ). In period 2, labour demand is larger than labour supply due to the decrease in the wage level in region $A$, and vice versa for region $B$. For region $A$ this is illustrated by equation (5):

$$
\begin{aligned}
& L_{C}^{A}=\left(L_{D, 2}^{A}-L_{D, 1}^{A}\right)-\left(L_{S, 2}^{A}-L_{S, 1}^{A}\right) \\
& =-\left(\beta_{2}^{A}+\alpha_{2}^{A}\right)\left(W_{2}^{A *}-W_{1}^{A *}\right) \\
& =-\gamma^{A}\left(W_{2}^{A *}-W_{1}^{A *}\right)>0
\end{aligned}
$$

$L_{C}^{A}$ is larger than zero since $\gamma^{A}>0$ and $W_{2}^{A^{*}}<W_{1}^{A^{*}}$. The parameters $\gamma^{A}$ and $\gamma^{B}$ can be interpreted as the sensitivity of commuting flows to wage adjustments within a region. A large $\gamma$ refers to high wage elasticities of supply and demand. By definition it holds that:

$$
L_{C}^{A}+L_{C}^{B}=0
$$

Therefore:

$$
\begin{aligned}
& -\gamma^{A}\left(W_{2}^{A *}-W_{1}^{A *}\right)-\gamma^{B}\left(W_{2}^{B *}-W_{1}^{B *}\right)=0 \\
& \frac{W_{1}^{A *}-W_{2}^{A *}}{W_{2}^{B *}-W_{1}^{B *}}=\frac{\gamma^{B}}{\gamma^{A}}
\end{aligned}
$$

Equation (7) implies that regions with relatively low wage elasticities are confronted with relatively large changes in the regional equilibrium wage due to commuting. The equilibrium wage levels in period 2 for region $A$ and $B$ are identical if there are no fixed costs. To commute from region $B$ to region $A$, workers have to incorporate the fixed costs $F$. Therefore, the difference between the equilibrium wage levels in period 2 consists of the fixed costs $F$ (see 
equation 4). Combining (7) with (4) results in:

$$
W_{2}^{A *}=\frac{\gamma^{B}}{\gamma^{B}+\gamma^{A}}\left(W_{1}^{B *}+F\right)+\frac{\gamma^{A}}{\gamma^{B}+\gamma^{A}} W_{1}^{A *}
$$

Equation (8) shows that the new equilibrium wage level in region $A$ is the weighted average of the old equilibrium wage levels in regions $A$ and $B$ corrected for fixed costs. The region with the largest wage elasticities has the largest weight. From equation (5) it follows that:

$$
W_{2}^{A *}=\frac{-L_{C}^{A}}{\gamma^{A}}+W_{1}^{A *}
$$

The next subsections test the relationship between the wage variance (in period 2, i.e. based on the observed wages) and the commuting flows. This relationship is predicted by the next equation, which can be derived by combining equations (6) and (9) for regions $A$ and $B$ :

$$
\begin{aligned}
& W_{2}^{A *}-W_{2}^{B *} \\
& =\left(\frac{-L_{C}^{A}}{\gamma^{A}}+W_{1}^{A *}\right)-\left(\frac{-L_{C}^{B}}{\gamma^{B}}+W_{1}^{B *}\right) \\
& =-\frac{\gamma^{B}+\gamma^{A}}{\gamma^{B} \gamma^{A}}\left(L_{C}^{A}\right)+\left(W_{1}^{A *}-W_{1}^{B *}\right)
\end{aligned}
$$

From equation (10) it can be readily understood that the interregional wage difference in period 2 , which is equal to the fixed costs of commuting as follows from equation (4), is dependent on the wage elasticities and the interregional wage difference in period 1, which are both predetermined. It follows that for given wage elasticities and interregional wage differences when regions are closed (in period 1) the magnitude of the observed commuting flows is negatively related to the observed interregional wage differences (in period 2, i.e. when regions are open). The larger the commuting flows between regions, the lower the interregional wage differences. Both commuting flows and interregional wage differences reflect the commuting conditions mentioned before.

Since higher wages will raise housing prices and will pull more individuals to the labour market, higher costs of commuting might also be reflected in larger interregional differences in housing prices and labour participation (i.e. employment rates). Finally, since job searchers face relatively high costs of commuting between municipalities of different regions, low commuting flows between regions may be related to large interregional differences in unemployment rates.

The four economic indicators that follow from the above analysis are widely used indicators when analysing regional disparities. This is evident not only from a study by the OECD (2005) on the persistence of regional disparities in OECD countries, but also from a number of recent publications for the Netherlands. These studies include Atzema and VAn Dijk (2005) on unemployment rates; VERMEULEN (2005) on regional employment and unemployment rates; and Vermeulen and VAN OMmeren (2006) on unemployment, housing prices, and wages. Moreover, for many other small countries contributions on regional disparities with respect to these indicators can be found in the work of FELSENSTEIN and PORTNOV (2005b). Finally, Hazans (2004) has found empirical evidence in line with the above commuting model. He shows that commuting significantly reduces wage disparities between areas in Estonia, Latvia, and Lithuania, and increases the employment possibilities of the residents in these countries.

\section{Descriptive statistics of economic indicators for labour market} coherence

Below will be given a description of the mean and standard deviation of the indicators following from the commuting model. This will be done for the four administrative and functional regions distinguished in the previous subsection. The calculation of the mean and standard deviation per administrative or functional region is based on the indicators of the municipalities for which data are available. The first indicator concerns the average wage level per worker. This indicator can be measured by, for example, gross earnings paid by the employer. These data are, however, not available at the municipality level for the Netherlands. Therefore, the net personal income of workers, which incorporates the gross wages earned as well as income taxes, tax allowances, and fiscal deductions, has been used. The income data have been drawn from the same survey as the travel-to-work data of the second section (OVG of Statistics Netherlands).

Moreover, data on housing prices were drawn from Statistics Netherlands that processed the data collected by the tax authorities. The housing prices are based on the tax declarations by homeowners in the Netherlands. Finally, the employment and unemployment rates are based on the Labour Force Survey of Statistics Netherlands. However, data on the employment and unemployment rate at municipality level were only available for municipalities with more than 10000 inhabitants. For these two indicators, data for 300 municipalities were used in the analysis. For housing prices, employment and unemployment rates no data were available for 1991. Table 1 gives an overview of the average values and standard deviations with regard to the four economic indicators for the municipalities in the four administrative regions of the Netherlands. The North region traditionally has the lowest labour participation, as indicated by the employment and unemployment rates. In the West region the income level, housing prices, and labour participation rates are the highest. 
Table 1. Overview of the statistics of the four administrative regions of the Netherlands, 2001

\begin{tabular}{lcccr}
\hline $\begin{array}{l}\text { Administrative } \\
\text { regions }\end{array}$ & $\begin{array}{c}\text { Income } \\
\text { level }(€)\end{array}$ & $\begin{array}{r}\text { Standard } \\
\text { deviation }\end{array}$ & $\begin{array}{c}\text { Housing } \\
\text { prices } € \text { €) }\end{array}$ & $\begin{array}{r}\text { Standard } \\
\text { deviation }\end{array}$ \\
\hline North & 17688 & 3154 & 47774 & 9992 \\
East & 17362 & 3617 & 66402 & 10432 \\
West & 18247 & 4624 & 71312 & 20969 \\
South & 17747 & 4138 & 70785 & 10909 \\
Total & 17874 & 4143 & 67051 & 17611 \\
& Employment & & Unemployment & \\
& rate $(\%)$ & & rate (\%) & \\
\cline { 2 - 4 } & 61.20 & 3.54 & 5.01 & 2.16 \\
North & 64.49 & 3.87 & 3.31 & 1.33 \\
East & 66.19 & 4.29 & 3.07 & 1.37 \\
West & 64.16 & 3.52 & 3.17 & 1.44 \\
South & 64.67 & 4.22 & 3.39 & 1.62 \\
Total & & & &
\end{tabular}

Source: Statistics Netherlands.

The same overview is presented in Table 2 for the four functionally delimited regions. In the functional division the regions of Utrecht and Zeeuws Vlaanderen have the most extreme values for the four indicators. In Utrecht the income level, housing prices, and labour participation are the highest; in Zeeuws Vlaanderen they are the lowest (except for the income level).

\section{Specification of the test}

To test for the coherence of the regions, regression analyses were carried out using standard ordinary least-squares (OLS) regression. The average values of the economic indicators of the municipalities in the functional or administrative regions were regressed on the dummy variables of the regions to account for the

Table 2. Overview of the statistics of the four functional regions of the Netherlands, 2001

\begin{tabular}{|c|c|c|c|c|}
\hline $\begin{array}{l}\text { Functional } \\
\text { regions }\end{array}$ & $\begin{array}{l}\text { Income } \\
\text { level }(€)\end{array}$ & $\begin{array}{l}\text { Standard } \\
\text { deviation }\end{array}$ & $\begin{array}{l}\text { Housing } \\
\text { prices }(€)\end{array}$ & $\begin{array}{l}\text { Standard } \\
\text { deviation }\end{array}$ \\
\hline $\begin{array}{l}\text { Zeeuws } \\
\text { Vlaanderen }\end{array}$ & 17893 & 2909 & 38721 & 3780 \\
\hline South & 17911 & 4166 & 69043 & 13645 \\
\hline Utrecht & 17974 & 4170 & 84961 & 22598 \\
\hline North & 17775 & 4107 & 60984 & 16899 \\
\hline Total & 17874 & 4143 & 67051 & 17611 \\
\hline & $\begin{array}{l}\text { Employment } \\
\text { rate }(\%)\end{array}$ & & $\begin{array}{l}\text { Unemployment } \\
\text { rate }(\%)\end{array}$ & \\
\hline $\begin{array}{l}\text { Zeeuws } \\
\text { Vlaanderen }\end{array}$ & 62.53 & 4.20 & 4.90 & 2.00 \\
\hline South & 65.07 & 4.13 & 3.20 & 1.41 \\
\hline Utrecht & 66.77 & 4.17 & 2.74 & 1.58 \\
\hline North & 63.74 & 4.18 & 3.76 & 1.75 \\
\hline Total & 64.67 & 4.22 & 3.39 & 1.62 \\
\hline
\end{tabular}

Source: Statistics Netherlands. differences in average income levels, housing prices, and employment and unemployment rates between regions. The question in this context is whether there are any significant differences between the different clusters of municipalities with regard to these economic indicators. The following equation was estimated to reveal the average income differences between functional or administrative regions:

$$
\text { Income }_{m}=\beta_{0}+\beta_{1, \ldots, k}{ }^{*} \text { delimitation }
$$

where $m$ is the municipalities; $k$ is the number of regions minus $1 ; \beta_{0}$ is the average income level of the reference region; and $\beta_{1, \ldots, k}$ is the differences between the average income level of the other regions and the reference region. The regressions are repeated for all couples of regions (i.e. taking different reference regions) of the same functional or administrative division. The number of couples in the four, 12, 28 and 40 divisions is six, 66, 378 and 780 , respectively (i.e. $\left.(k+1)^{*} k / 2\right)$. Similar regression equations are estimated for housing prices, and employment and unemployment rates. Significant differences in economic indicators between regions indicate that the delimitation is based on coherent regions. Finally, the number of significant differences between the average levels of the economic indicators of regions were counted.

\section{Results}

The higher the number of significant differences between the regions in the estimated equations, the lower the interaction of workers between these regions, and the higher the coherence of the municipalities within the regions. Tables 3 and 4 show the mean differences of the four economic indicators of all possible combinations of the four administrative and functional regions, respectively. Remarkably, the differences in income levels are not significant between the administrative and functional regions. On the other hand, housing prices are significantly different for almost all the six pairs of regions. The employment and unemployment rates are significantly different for about half of the six pairs.

The positive and negative signs of the differences across the four economic indicators are generally in accordance with the predictions that follow from the commuting model presented above. In most cases a region with a lower average income level than another region also has a lower average housing price, a lower average employment rate, and a higher average unemployment rate relative to the other region. The North region, for example, has a lower income level than the West region - although not significantly so - a significantly lower housing price and employment rate, and a significantly higher unemployment rate than the West region. 
Table 3. Mean differences of the four economic indicators for the four administrative regions (NUTS1) of the Netherlands, 2001

\begin{tabular}{|c|c|c|c|c|c|}
\hline \multirow[b]{2}{*}{ (I) Region } & \multirow[b]{2}{*}{ (J) Region } & \multicolumn{2}{|c|}{ Income level } & \multicolumn{2}{|c|}{ Housing price } \\
\hline & & $\begin{array}{l}\text { Mean difference } \\
(\mathrm{I}-\mathrm{J})\end{array}$ & $p$-value & $\begin{array}{c}\text { Mean difference } \\
(\mathrm{I}-\mathrm{J})\end{array}$ & $p$-value \\
\hline \multirow[t]{3}{*}{ 1) North } & 2) East & 325 & 0.622 & $-18.625^{*}$ & 0.000 \\
\hline & 3) West & -560 & 0.343 & $-23.535^{*}$ & 0.000 \\
\hline & 4) South & -60 & 0.926 & $-23.011^{*}$ & 0.000 \\
\hline \multirow[t]{2}{*}{ 2) East } & 3) West & -884 & 0.079 & $-4.909^{*}$ & 0.011 \\
\hline & 4) South & -385 & 0.497 & $-4.385^{*}$ & 0.044 \\
\hline 3) West & 4) South & 499 & 0.303 & 0.524 & 0.778 \\
\hline \multirow[t]{2}{*}{ Number of significant differences } & Out of six & \multicolumn{2}{|l|}{0} & \multicolumn{2}{|l|}{5} \\
\hline & & \multicolumn{2}{|c|}{ Employment rate } & \multicolumn{2}{|c|}{ Unemployment rate } \\
\hline \multirow[t]{3}{*}{ 1) North } & 2) East & $-3.292^{*}$ & 0.000 & $1.698^{*}$ & 0.000 \\
\hline & 3) West & $-4.996^{*}$ & 0.000 & $1.939^{*}$ & 0.000 \\
\hline & 4) South & $-2.967^{*}$ & 0.000 & $1.835^{*}$ & 0.000 \\
\hline \multirow[t]{2}{*}{ 2) East } & 3) West & $-1.704^{*}$ & 0.003 & 0.241 & 0.270 \\
\hline & 4) South & 0.325 & 0.613 & 0.136 & 0.578 \\
\hline 3) West & 4) South & $2.029^{*}$ & 0.000 & -0.105 & 0.218 \\
\hline Number of significant difference & Out of six & 5 & & 3 & \\
\hline
\end{tabular}

Note: *Significantly different at the $5 \%$ level.

Tables 5 and 6 give a complete overview of the percentages of significant differences for the four economic indicators with respect to the four, 12, 28 and 40 functional and administrative delimitations in 2001 and 1991, respectively. For the income level in the 12, 28, and 40 division of regions, the functional delimitation performs slightly better than the administrative delimitation. It appears that in terms of average income level, the functionally defined regions have slightly more coherence than the administrative regions of the
Netherlands. The functional division of 12 regions has the best score, since $27 \%$ out of the 66 pairs of regions have a significantly different income level. For the other three economic indicators the performance is generally much higher for both the administrative and the functional delimitation. However, for these economic indicators the functional delimitation is not better than the administrative delimitation.

With respect to the four economic indicators it follows that the number of regions that are significantly

Table 4. Mean differences of the four economic indicators for the four functional regions of the Netherlands, 2001

\begin{tabular}{|c|c|c|c|c|c|}
\hline \multirow[b]{2}{*}{ (I) Region } & \multirow[b]{2}{*}{ (J) Region } & \multicolumn{2}{|c|}{ Income level } & \multicolumn{2}{|c|}{ Housing price } \\
\hline & & $\begin{array}{l}\text { Mean difference } \\
\quad(\mathrm{I}-\mathrm{J})\end{array}$ & $p$-value & $\begin{array}{l}\text { Mean difference } \\
\quad(\mathrm{I}-\mathrm{J})\end{array}$ & $p$-value \\
\hline \multirow[t]{3}{*}{ 1) Zeeuws Vlaanderen } & 2) South & -17 & 0.992 & $-30319^{*}$ & 0.000 \\
\hline & 3) Utrecht & -82 & 0.964 & $-46237^{*}$ & 0.000 \\
\hline & 4) North & 117 & 0.946 & $-22262^{*}$ & 0.001 \\
\hline \multirow[t]{2}{*}{ 2) South } & 3) Utrecht & -65 & 0.924 & $-15918^{*}$ & 0.000 \\
\hline & 4) North & 134 & 0.741 & $8058^{*}$ & 0.000 \\
\hline 3) Utrecht & 4) North & 199 & 0.773 & $23976^{*}$ & 0.000 \\
\hline \multirow[t]{2}{*}{ Number of significant difference } & Out of six & \multicolumn{2}{|l|}{0} & \multicolumn{2}{|l|}{6} \\
\hline & & \multicolumn{2}{|c|}{ Employment rate } & \multicolumn{2}{|c|}{ Unemployment rate } \\
\hline \multirow[t]{3}{*}{ 1) Zeeuws Vlaanderen } & 2) South & -2.532 & 0.297 & 1.697 & 0.066 \\
\hline & 3) Utrecht & -4.235 & 0.094 & $2.164^{*}$ & 0.025 \\
\hline & 4) North & -1.203 & 0.620 & 1.143 & 0.216 \\
\hline \multirow{2}{*}{ 2) South } & 3) Utrecht & $-1.702^{*}$ & 0.047 & 0.467 & 0.151 \\
\hline & 4) North & $1.329^{*}$ & 0.008 & $-0.555^{*}$ & 0.004 \\
\hline 3) Utrecht & 4) North & $3.031^{*}$ & 0.001 & $-1.021^{*}$ & 0.002 \\
\hline Number of significant difference & Out of six & 3 & & 3 & \\
\hline
\end{tabular}

Note: *Significantly different at the $5 \%$ level. 
Table 5. Percentages of significant differences (at the 5\% level) between the means of the economic indicators, delimitations of 2001

\begin{tabular}{|c|c|c|c|c|}
\hline \multirow[b]{2}{*}{ Indicator } & \multicolumn{2}{|c|}{ Four-region division } & \multicolumn{2}{|c|}{ 12-region division } \\
\hline & Administrative (\%) & Functional (\%) & Administrative (\%) & Functional (\%) \\
\hline Income level, 2001 & 0 & 0 & 0 & 27 \\
\hline Housing price, 2001 & 83 & 100 & 74 & 67 \\
\hline Employment rate, 2001 & 83 & 50 & 56 & 33 \\
\hline Unemployment rate, 2001 & 50 & 50 & 50 & 36 \\
\hline \multirow[t]{2}{*}{ Total } & 54 & 50 & 45 & 41 \\
\hline & \multicolumn{2}{|c|}{ 28-region division } & \multicolumn{2}{|c|}{ 40-region division } \\
\hline Income level, 2001 & 3 & 5 & 2 & 8 \\
\hline Housing price, 2001 & 58 & 62 & 55 & 49 \\
\hline Employment rate, 2001 & 38 & 36 & 24 & 20 \\
\hline Unemployment rate, 2001 & 28 & 40 & 29 & 24 \\
\hline Total & 32 & 36 & 28 & 25 \\
\hline
\end{tabular}

different from each other is more or less equal for the administrative and the functional 2001 delimitations. Only in the case of the 28 division of regions is the performance slightly better for functional delimitation. The differences in performance between the administrative and functional divisions of four, 12, 28 and 40 regions in 2001 are, however, small.

Table 6 shows the percentages of significant differences based on the 1991 delimitation of the Netherlands. For the interregional income differences in both 1991 and 2001, the functional 1991 delimitation performs better than the administrative delimitation (except for the 28 division with the 1991 average income level). As in 2001, the performance of the income level as an economic indicator of interregional differences is low. For the three other economic indicators one again finds relatively large percentages of significant differences between administrative and functional regions. The functional division performs slightly worse for these indicators with respect to the 12 and 24 division.

It is generally true that the more differentiated the delimitation, the worse the relative performance. This holds for both the administrative and functional delimitations. Although the absolute number of significant differences usually increases when the delimitation is more differentiated, it is concluded that there is no advantage to differentiate between relatively small regions.

\section{CONCLUSIONS}

In many delimitation studies the procedures and algorithms are adapted with respect to some thresholds to obtain 'satisfactory' results. This 'fine-tuning' is considered to be necessary but can also be regarded as rather arbitrary. The method applied in the present paper

Table 6. Percentages of significant differences (at the 5\% level) between the means of the economic indicators, delimitations of 1991

\begin{tabular}{|c|c|c|c|c|}
\hline \multirow[b]{2}{*}{ Indicator } & \multicolumn{2}{|c|}{ Four-region division } & \multicolumn{2}{|c|}{ 12-region division } \\
\hline & Administrative (\%) & Functional (\%) & Administrative (\%) & Functional (\%) \\
\hline Income level, 1991 & 0 & 0 & 0 & 8 \\
\hline Income level, 2001 & 0 & 17 & 0 & 18 \\
\hline Housing price, 2001 & 83 & 83 & 74 & 51 \\
\hline Employment rate, 2001 & 83 & 67 & 56 & 27 \\
\hline Unemployment rate, 2001 & 50 & 50 & 50 & 36 \\
\hline \multirow[t]{2}{*}{ Total } & 43 & 54 & 36 & 28 \\
\hline & \multicolumn{2}{|c|}{ 28-region division } & \multicolumn{2}{|c|}{ 40-region division } \\
\hline Income level, 1991 & 6 & 3 & 2 & 10 \\
\hline Income level, 2001 & 3 & 8 & 2 & 6 \\
\hline Housing price, 2001 & 58 & 50 & 55 & 56 \\
\hline Employment rate, 2001 & 38 & 28 & 24 & 29 \\
\hline Unemployment rate, 2001 & 28 & 21 & 29 & 29 \\
\hline Total & 27 & 22 & 22 & 26 \\
\hline
\end{tabular}


avoids the use of a set of more or less arbitrary criteria by transforming the standard interaction matrix of commuting flows between municipalities into an MFPT matrix and applying the Ward clustering procedure. To compare the functionally defined regions with the administrative ones, the number of functional regions was tuned to the number of regions of the administrative delineation.

This paper argues that no matter what delimitation method is used, the resulting functional division of regions should be tested against the administrative division using a set of relevant criteria. Both from the commuting model presented in this paper and the reviewed empirical studies on regional disparities, it follows that one can distinguish four economic indicators of labour market coherence: income level, housing prices, employment rate, and unemployment rate. For these indicators it was tested whether the municipalities within the functionally defined regions show more coherence (i.e. smaller disparities) than the municipalities within the administratively defined regions.

For both 1991 and 2001 it appears that, in terms of income level, the functional regions have slightly more coherence than the administrative regions. The performance of income level as an economic indicator of differences between regions, however, was much worse than for the other economic indicators. A possible reason for the low percentage of significant differences in the income levels between regions is that income is in fact an approximation for the wages of individual workers. For the other three economic indicators the functional and the administrative regions showed, on average, the same coherence for both 1991 and 2001. It can be concluded that the administrative delimitation of the Netherlands performs, on average, equally well as the functional delimitation. The hypothesis that the municipalities within the administratively defined regions show less coherence than the municipalities within the functionally delimited regions cannot be rejected.

The results imply that it is important in delimitation studies to test the functional divisions of regions against the administrative division with respect to a set of relevant indicators. If the functional divisions do not outperform the administrative division with respect to these indicators, there is not much to be gained in policy-making by using a particular functional division. Other reasons for particular delimitations of regions, such as the existence of regional administrative and governmental bodies and the managerial control over regions, may then be more important. However, in the numerous delimitation studies for many different countries and regionalization procedures there is hardly given any information on whether the functional divisions of regions can outperform the administrative division of regions. Therefore, future research on this subject should include this information.

Finally, the results imply that it might be better for regional labour market policies not to use a highly differentiated division of regions for small countries such as the Netherlands. In general, the regionalization of the Netherlands into four regions seems to be sufficient. On the one hand, this conclusion is supported by the empirical study by Vermeulen (2005), who finds that the differences between Dutch regions in employment and unemployment rates are rather limited. On the other hand, Vermeulen finds larger disparities between regions for women, low age groups, and the lower educated. Moreover, according to FELSENSTEIN and PORTNOV (2005a) there are no a priori arguments to expect that small countries will have fewer disparities between regions than larger countries. More research is required to find appropriate regionalizations of the labour market for both small and large countries.

Acknowledgements - This research was granted by the Dutch Ministry of Economic Affairs. The authors would like to thank Jacco Hakfoort, Marcel van Wijk, Christoph Meng, and three anonymous referees for their valuable comments on earlier versions of this paper.

\section{APPENDIX 1: MEAN FIRST PASSAGE TIME (MFPT) METHOD}

\section{From Markov chain to MFPT}

To compute the MFPT matrix, the daily travel-to-work commuting flows of workers are regarded as a Markov chain. A Markov chain is a stochastic process that describes the transition from one state to another over time using probabilities. By using a Markov chain it is possible to re-enter each state at any point in time (i.e. $\sum_{j} P_{i, j}=0$ for some $i$, where $p_{i, j}$ is element ( $i$, $j$ ) of matrix $\lim _{t \rightarrow \infty}\left(P^{t}\right)$ ), and compute the average number of transitions needed to arrive from origin $i$ in destination $j$ for the first time. Note that because the probabilities of going from $i$ to $j$ are generally not equal to the probabilities of going from $j$ to $i$ by construction, the MFPT matrix is asymmetric. Since MASSER and Scheurwater (1980) argued in favour of using a destination-based instead of an origin-based probability matrix when handling travel-to-work flows, the destination-based approach is used throughout this paper.

\section{Computation of the MFPT}

For the Markov chain with a single-period transition matrix $P$, the $j$-period transition matrix is defined by $P^{\mathrm{t}}$. If this process is run for an indefinite time span, one ends up with in an equilibrium state. The proportions of time spent in each state are then $\lim _{t \rightarrow \infty} P^{\mathrm{t}}=$ $A$, where $A$ is the limit matrix. Having these two matrices, one can compute the so-called fundamental 
matrix $Z$ of the process. $Z$ can be computed by:

$$
Z=(I-(P-A))^{-1}
$$

where $I$ is the identity matrix. From the limit matrix, matrix $D$ is defined by $1 / a_{i}$ on its diagonal and zeros for all other elements. The MFPT matrix can then be computed by:

$$
M=\left(I-Z+E Z_{\text {diag }}\right) D
$$

where $E$ is a matrix containing 1 's everywhere and $Z_{\text {diag }}$ is the matrix containing the diagonal elements of $Z$ and zeros for all other elements (also LEMAY, 1999).

\section{Properties and interpretation of the MFPT matrix}

First, the diagonal elements of the MFPT matrix are very small; this indicates that there are many travel-towork flows within a region, which is something quite intuitive. Furthermore, all other values in the columns are relatively close to the column average, i.e. they are of the same order. These column averages are indicators for how much attraction in which a region has to work. The lower the column average, the more attractive is the region.

\section{From MFPT to distances}

The asymmetry observed for the MFPT matrix is particularly inconvenient to cluster regions, as clustering procedures often implicitly assume symmetric distances. Another problem arising from the MFPT is that the order of the column averages differs considerably among columns, which might result in the clustering of all larger regions together, even though the distance in kilometres between these regions is very large. In fact, the authors wanted to cluster the regions in such a way that the variation within clusters was minimal. Therefore, one needs appropriate measures of variation. The problem of differences in the order of column averages is solved by taking the $z$-values, which are defined by:

$$
z_{i j}=\frac{x_{i j}-\mu_{j}}{\sigma_{j}}
$$

Note that although the diagonal values of this $z$-matrix can be computed, they make no sense and should be equal to zero or even non-existent. From these zvalues one obtains a measure for how close regions $i$ and $j$ are to each other. This is done with a so-called squared distance matrix. For each column $k$, one can compute the difference between $z_{i k}$ and $z_{j k}$ (where $i, j \neq k$ ) and square it. This is the marginal contribution from $k$ to the squared distance. This can be written as:

$$
d_{i, j}=\sqrt{\left(\sum_{k: i, j \neq k}\left(z_{i k}-z_{j k}\right)^{2}\right)}
$$

By construction, $d_{i j}=d_{j i}$, so this transformation also handles all other problems.

\section{NOTES}

1. This problem refers to the 'scale problem' mentioned in the Introduction.

2. This problem refers to the 'aggregation problem' mentioned in the Introduction.

3. For more details on the commuting flows in the Netherlands, see Corpelijn and HeErschop (2002).

4. In 1991 and 2001 two car ferries were running across the Westerschelde estuary. In 2003 the Westerschelde tunnel was put into use and the car ferry services were stopped.

5. This paper abstracted from other factors that might determine wage inequality between regions, such as regional differences in the educational structure of the population and the economic structure of regions with respect to sectors of industry and occupations. In addition, the analysis of the impact of national collective agreements on reducing wage inequality is beyond the scope of the paper.

\section{REFERENCES}

AMEdo D. (1968) An optimization approach to the identification of a system of planning regions, Regional Science Association 23, 25 -44. ANDERSEN A. K. (2002) Are commuting areas relevant for the delimitation of administrative regions in Denmark?, Regional Studies 36, 833-844.

Atzema O. and Van Dijk J. (2005) The persistence of regional unemployment disparities in the Netherlands, in Felsenstein D. and Portnov B. A. (Eds) Regional Disparities in Small Countries, pp. 147-167. Springer, Heidelberg.

BALL R. M. (1980) The use and definition of travel-to-work areas in Great Britain: some problems, Regional Studies 14, 125-139.

Baumann J. H., Fischer M. M. and Schubert U. (1996) A multiregional labour supply model for Austria: the effects of different regionalisations in multiregional labour market modelling, in Fischer M. M., Button K. J. and NijkAMP P. (Eds) Regional Housing and Labour Markets, pp. 366-396. Reference Collection Vol. 5. Edward Elgar, Cheltenham.

Bongaerts D., Cörvers F. and Hensen M. (2004) The Delimitation and Coherence of Functional and Administrative Regions. Research Series No. 04O19. Ministry of Economic Affairs, The Hague.

Brown L. A. and Holmes J. (1971) The delimitation of functional regions, nodal regions, and hierarchies by functional distance approaches, Journal of Regional Science 11, 57-72. 
Casado-Díaz J. M. (2000) Local labour market areas in Spain: a case study, Regional Studies 34, 843-856.

Coombes M. (2005) Multiple dimensions of settlement systems: coping with complexity, in ChAmPiON T. and HUGO G. (Eds) New Forms of Urbanization, Beyond the Urban-Rural Dichotomy, pp. 307-324. International Union for the Scientific Study of Population. Ashgate, Aldershot.

Coombes M. G. and Openshaw S. (1982) The use and definition of travel-to-work areas in Great Britain: some comments, Regional Studies 16, 141-149.

Coombes M. G., Green A. E. and Openshaw S. (1986) An efficient algorithm to generate official statistical reporting areas: the case of the 1984 travel-to-work-areas revision in Britain, Journal of the Operational Research Society 37, 943-953.

Corpelijn A. W. F. and Heerschop M. J. (2002) Inkomende en Uitgaande Pendel, 1998. Sociaal-Economische Maandstatistiek No. 2002/12, pp. 53-57. Statistics Netherlands, Voorburg/Heerlen.

Eurostat (1992) Study on Employment Zones. E/LOC/20. Eurostat, Luxembourg.

Felsenstein D. and Portnov B. A. (2005a) Understanding regional inequalities in small countries, Regional Studies 39, 647-658.

Felsenstein D. and Portnov B. A. (Eds) (2005b) Regional Disparities in Small Countries. Springer, Heidelberg.

Fischer M. M. (1980) Regional taxonomy: a comparison of some hierarchic and non-hierarchic strategies, Regional Science and Urban Economics 10, 503-537.

Fox K. A. and Kumar T. K. (1965) The functional economic area: delineation and implications for economic analysis and policy, Regional Science Association Papers 15, 57-85.

Giulliano G. and Small K. A. (1991) Subcenters in the Los Angeles region, Regional Science and Urban Economics 21, $162-182$.

Green A. E. and Coombes M. G. (1985) Local unemployment rates: statistical sensitivities and policy implications, Regional Studies 19, 268-273.

Hazans M. (2004) Does commuting reduce wage disparities?, Growth and Change 35, 360-390.

Killian M. S. and Tolbert C. M. (1993) Mapping social and economic space: the delineation of local labor markets in the United States, in Singelmann J. and Deseran F. A. (Eds) Inequalities in Labor Market Areas, pp. 69-79. Westview, Boulder, CO.

Lemay P. (1999) The Statistical Analysis of Dynamics and Complexity in Psychology: A Configural Approach. University of Lausanne, Lausanne (available at: http://tecfa.unige.ch/ lemay/thesis/THX-Doctorat).

Masser I. and Brown P. J. B. (1975) Hierarchical aggregration procedures for interaction data, Environment and Planning A 7, $509-523$.

MAsser I. and Scheurwater J. (1980) Functional regionalisation of spatial interaction data: an evaluation of some suggested strategies, Environment and Planning A 12, 1357-1382.

Musterd S. and Van Zelm I. (2001) Polycentricity, households and the identity of places, Urban Studies 38, 679-696.

Newell J. O. and Papps K. L. (2002) Identifying Functional Labour Market Areas in New Zealand: A Reconnaissance Study using Travelto-Work Data. IZA DP No. 443. Institute of the Study of Labor, Bonn.

Organization for Economic Co-operation and Development (OECD) (2002) Redefining Territories, The Functional Regions. OECD, Paris.

Organization for Economic Co-operation and Development (OECD) (2005) OECD Employment Outlook. OECD, Paris.

Office for National Statistics (ONS) and Coombes M. G. (1998) 1991-Based Travel-to-Work Areas. ONS, London.

Openshaw S. (1984) The Modifiable Areal Unit Problem. Concepts and Techniques in Modern Geography No. 38. Geo Books, Norwich.

Ritsema Van Eck J., Van Oort F., Raspe O., Dahlhuizen F. and Van Brussel J. (2006) Veel Steden maken nog geen Randstad [Many Towns Do Not a Randstad Make]. Netherlands Institute for Spatial Research, NAi Uitgevers RPB, Rotterdam/The Hague.

Sforzi F., Openshaw S. and Wymer C. (1997) Le procedura di identificazione dei sistemi locali del lavoro, in SFORZI F. (Ed.) I Sistemi Locali del Lavoro 1991, pp. 235-242. ISTAT, Rome.

Smart M. W. (1974) Labour market areas: uses and definitions, Progress in Planning 2, 238-353.

UNWIN D. J. (1996) GIS, spatial analysis and spatial statistics, Progress in Human Geography 20, 540-551.

VAn Der LaAn L. and Schalke R. (2001) Reality versus policy: the delineation and testing of local labour market and spatial policy areas, European Planning Studies 9, 201-221.

Vermeulen W. (2005) Regional disparities in small countries? Paper presented at the ERSA Conference, Amsterdam, the Netherlands, 2005.

Vermeulen W. and Van Ommeren J. (2006) Compensating of Regional Unemployment in Housing Markets. Discussion Paper No. 57. CPB, The Hague.

WARD J. H. (1963) Hierarchical grouping to optimise an objective function, Journal of the American Statistical Association 58, 236-244. 